International Journal of Education, Learning and Development

Vol.8, No.1, pp.51-65, January 2020

Published by ECRTD-UK

Print ISSN: 2054-6297(Print), Online ISSN: 2054-6300(Online)

\title{
EXAMINATION ANXIETY UNMASKED: PREDICTORS AND COPING STRATEGIES AS EXPERIENCED BY JUNIOR HIGH SCHOOL STUDENTS IN THE EFFUTU MUNICIPALITY OF GHANA
}

\section{${ }^{1}$ Joseph Bentil, ${ }^{2}$ Simon Kormla Donkor, ${ }^{3}$ Janet Agyarkwaa Oti and ${ }^{4}$ Nixon Saba Adzifome University of Education, Winneba, GHANA}

\author{
1, 2 \& 4 (Department of Basic Education, University of Education, Winneba, GHANA) \\ ${ }^{3}$ (Department of Home Economic Education, University of Education, Winneba, GHANA) \\ *Corresponding Email:joseph_bentil@yahoo.com
}

\begin{abstract}
This study investigated the factors that trigger examination anxiety while exploring coping strategies needed to reduce anxiety among Junior High School students in the Effutu Municipality. The study employed the cross-sectional descriptive survey design with quantitative approach where through proportionate stratified random sampling, a sample of 746 students was obtained from both public and private Junior High Schools in the three (3) circuits of the Effutu Municipality. Data was collected using a structured questionnaire and analyzed using both descriptive and inferential statistics. The study revealed that even though different kinds of factors trigger examination anxiety amongst the students, lack of self-esteem was the most dominant factor while subject load of the students recorded the least influence on examination anxiety. The study further established that good study habits and skills, effective teacher support, motivation, reduction of students' workload, improvement in co-curricular activities, and having enough sleep and rest time were the coping strategies advanced to reduce examination anxiety. Additionally, it was found that factors such as having low self-confidence, past experience and beliefs about examination, history of consistent poor performance, subject load, and psychological factors jointly contributed significantly to examination anxiety among students. Besides, motivation of students, reduction of subject load and good teachers support for students were the coping strategies needed to manage examination anxiety. Based on these results, it was recommended that regular education programmes such as symposia and school festivals should be conducted to heighten students' self-esteem, and remove negative past experiences and beliefs about examinations while exploring other coping strategies to reduce examination anxiety for improved academic performance.
\end{abstract}

KEYWORDS: examination anxiety, factors, coping strategies, academic achievement, junior high school

\section{INTRODUCTION}

The concept of examination anxiety is not a new educational phenomenon and has been one of the major concerns of educational psychologist as a barrier to promoting effective learning and realizing good academic achievement in any educational institution. Supporting these claims, 
International Journal of Education, Learning and Development

Vol.8, No.1, pp.51-65, January 2020

Published by ECRTD-UK

Print ISSN: 2054-6297(Print), Online ISSN: 2054-6300(Online)

educational researchers and academicians like Mavilidi, Hoogerheide and Paas (2014) observed that typically a student's academic journey entails several evaluative circumstances aimed at determining students learning and the general quality of education which however trigger anxiety. In line with this assertion, Oladipo, Ogungbamila and Idemudia (2015) noted that in today's competitive academic environment, tests and examinations are not only endemic at all levels of education but have been considered as central and crucial tools for decision making in today's competitive society. In essence, tests and examination are unavoidable and ubiquitous in students' academic life. Accordingly, research on examination anxiety and its impact on students' academic performance has received considerable attention in recent decades.

It is construed from the foregoing comments that examination anxiety is inevitable amongst students in all academic environments because once there are tests and examinations, anxiety will emerge and fester. Considered as a multi-dimensional phenomenon that involves worry, emotionality, and behavioural response to being preoccupied by the possible negative outcome of academic scores (Chapell, Blanding, Takahashi, Silverstein, Newman, Gubi \& Mccann, 2005), test anxiety also relates to the subjective feeling of tension, apprehension, nervousness, and worry associated with an arousal of the automatic nervous system. Deductively, the above definitions suggest that examination anxiety is the feeling of apprehension which learners portray due to their perception of undesirable outcome of an impending examination and that examination anxiety is a personal expression of fear in relation to an examination. In this study, examination anxiety is defined as the individual expression of fear associated with the outcome of examinations. It is, therefore, evident that total elimination of examination anxiety cannot be thought of because it is pervasive in all academic endeavours however, should be well managed to forestall any ripple effects.

Extant literature has documented various effects of examination anxiety on student effectiveness in schools. Studies around the world show that high examination anxiety has paralyzing effects on the academic success of students across educational levels (Hoferichter, Raufelder, \& Eid, 2014; Syokwaa, Aloka, \& Ndunge, 2014; Mondal, Ghosh, \& Das, 2013), even though researchers like Cherry (2012) maintain that students who exhibit moderate levels of examination anxiety are able to perform relatively well on examinations. These studies suggest that high examination anxiety stifles students' academic achievement while moderate levels of examination anxiety is expected among students as this feeling bolster their academic performance. Scholars have demonstrated that students with severe anxiety experience panic with common physical symptoms which include headache, upset stomach, feeling of fear, shortness of breath, sweating, pacing or fidgeting, crying, racing thoughts and blanking out which negatively affect their academic achievement (Khan, Haider, Ahmed, \& Khan, 2011; Karimi \& Venkatesan, 2009). These authors explained that test anxiety creates irrelevant thought, decreased attention and concentration which lead to academic failure. Meanwhile reserachers have maintained that a moderate level of examination anxiety is essential for better academic performance, and the absence of anxiety ultimately lead to poor academic performance among students (Driscoll et al., 2009). This finding buttresses the claim that some amount of 
International Journal of Education, Learning and Development

Vol.8, No.1, pp.51-65, January 2020

Published by ECRTD-UK

Print ISSN: 2054-6297(Print), Online ISSN: 2054-6300(Online)

examination anxiety is vital for good academic achievement. It is inferred from the perspective of these scholars that educational actors and researchers need to make conscious efforts to reduce anxiety levels of students so as to reap the benefits therein.

Taking cognizance of the deleterious consequences of examination anxiety on students and the fact that examination anxiety is closely linked with students' performance, researchers have begun to unearth the factors that spur anxiety. Indeed, as a result of empirical studies, scholars have uncovered a myriad of factors that directly trigger examination anxiety among students. For instance, Vaz, Pothiyil, George, Alex, Pothiyil, Kamath (2018) identified factors such as learning process, students' perception related to examination, learning pattern, and the over expectations related to learning outcome influence examination anxiety. Chapell, Blanding, Silverstein, Takashi, Newman and Gubi (2005) unveiled a plethora of factors that activate to the development of examination anxiety which include fear of failing, consistently thinking about consequences of failure, procrastination, poor study habit, inadequate knowledge of course materials, consistent poor performance, past experiences and beliefs, and lack of confidence in one's ability. Accordingly, it could be said that academic achievement of students is not mainly contingent on an individual's cognitive prowess as experience of any of the aforementioned factors can impede the academic achievement of students. This situation, therefore, requires that school administrators and examination authorities explore various strategies to address examination anxiety levels of students.

Duraku (2016) identifies lack of preparation, fear of failing, family responsibilities, characteristics of the professor and exam, lack of time management skills, and lack of study skills as factors related to test anxiety. This resonates with Patil and Aithala's (2017) research findings which fingered examination system, as well as lack of time management and extensive course load as the major contributing factors for anxiety related to the examination. Juxtaposing these results, it could be said that, the literature reviewed has catalogued diverse factors that influence test anxiety. These factors could be categorized as environmental, personal and psychological factors. According to Aremu and Sokan (2003) environmental factors influence test anxiety. Implicitly, dilapidated school buildings, poor ventilated classrooms, and unfriendly invigilators have the potential to increase the anxiety level of students. These results suggest that students' academic achievement is likely to be improved if these factors are eliminated. Accordingly, these situations enjoin school administrators and examination authorities to make strenuous effort to create conducive and stress-free environment for students during examinations. The literature has unveiled that examination anxiety is activated by different factors. However, in this study, factors such as psychological factors, study skill, self-esteem, course load, consistent poor performance and past experiences and beliefs were investigated.

In an attempt to reduce the influence of the aforementioned factors on examination anxiety, researchers have explored and proffered various coping strategies that could be deployed. Hashemi and Mashayekh (2011) explained that the best way to reduce anxiety is to work on personal health, diet, exercise, and sleep. Their suggestions continue to explain that improving 
International Journal of Education, Learning and Development

Vol.8, No.1, pp.51-65, January 2020

Published by ECRTD-UK

Print ISSN: 2054-6297(Print), Online ISSN: 2054-6300(Online)

self-image, motivation, and attitudes can help reduce anxiety. Mashayekh and Hashemi (2011) added clarity to this viewpoint when they noted in their study on recognizing, reducing and coping with examination anxiety that besides improving one's self-image, motivation and attitude, maintaining good health, exercise, diet, and rest exercise can assist in making one take his/her mind off worries and concerns about the test and maintained that the aforementioned strategies also serve as outlets for anger and other negative emotions that feed trigger anxiety. Marszal-Wiśniewska, Gorynska and Strelau (2011) found motivation as a significant factor in reducing examination anxiety. They found out that students felt both positive and negative emotions before, during, and after an examination. However, students who are motivated had higher levels of emotional functioning when faced with anxiety during the examination. Bensoussan (2012) found out that teachers' willingness to work with their students to enhance their examination scores has a positive effect on reducing examination anxiety. Bensoussan established that students felt less anxiety about examination when a class discussion was held about the examination. Bensoussan (2012) further noted that students felt better about examination when given the opportunity for bonus questions. This enhances the students chances of obtaining better grades, hence reduces their anxiety levels.

Maharajan, Rajiah, Tam, Chaw, Ang and Yong (2017) note that academic support in the form of teacher support mechanisms are among the powerful factors in coping and dealing with anxiety. Xiao (2013) suggests that reducing students' academic workloads improve students' mental and physical health. Xiao further enumerated strategies to reduce examination anxiety among students which include improving extracurricular opportunities, and strictly following the schools' study and recess time schedules. Others include having enough sleep and rest time, and ensuring student-centered education system even though Lawrence-Arul (2014) discovered no significant relationship between study habits and test anxiety of students. It is inferred from Xiao's revelation that the predictors of examination anxiety are the heavy academic workloads among students which consist of excessive curriculum subjects, homework, and examinations. It is, therefore, required that schools at all levels endeavour to adjust school curriculum subjects appropriately and reduce the total study hours each week. Accordingly, policy makers in education are expected to reduce the number of subjects in the curriculum so as to lessen the work load of students if the desire is to see better academic performance.

Available literature suggests that there is consensus among researchers that examination anxiety stifles students' academic achievement (Hoferichter et al., 2014; Syokwaa et al., 2014; Mondal et al., 2013). In essence, the key to improving students' academic achievement is to uncover the factors that trigger examination anxiety. In pursuance of this thought, researchers have investigated the factors that influence examination anxiety. However, there is lack of consensus among researchers on the exact factor(s) that influence examination anxiety and the best coping strategy that could be applied to reduce anxiety in all contexts. Therefore, it is important to explore factors that trigger examination anxiety in specific settings that would lead to identification of the best coping strategies for dealing with examination anxiety. It is against this background that this study was carried out to investigate the factors that influence examination 
International Journal of Education, Learning and Development

Vol.8, No.1, pp.51-65, January 2020

Published by $\boldsymbol{E C R T D}-\boldsymbol{U K}$

Print ISSN: 2054-6297(Print), Online ISSN: 2054-6300(Online)

anxiety as well as the coping strategies for managing anxiety among Junior High School students in the Effutu Municipality of Ghana.

The following research questions guided the study:

1. What factors influence examination anxiety among Junior High School students in the Effutu Municipality?

2. What coping strategies are effective in managing examination anxiety among Junior High School students in the Effutu Municipality?

3. To what extent does the factors (low self-confidence, psychological factors, subject load, history of consistent poor results, past experiences and beliefs about examination, study skills and habits) influence examination anxiety in Junior High Schools in the Effutu Municipality?

4. Relative to one another, which coping strategies (good study habits, having sleep and rest time, reduction of subject load, effective teacher support, improvement of co-curricular activities, motivation of students) better reduce examination anxiety among Junior High School students in the Effutu Municipality?

The findings of the study will be beneficial to several education stakeholders. Stakeholders at all levels of education need empirical data regarding the causes of examination anxiety and academic achievement. It is anticipated that the findings from this study will contribute to knowledge on the problem of students' declining academic achievement and anxiety as its antecedent. It is expected that this knowledge will inform educators a basis for teachers, school administrators and parents to implement suitable strategies that would help reduce the causes of test anxiety on students' academic achievement as school administrators will also see the need to provide conducive atmosphere for instruction and assessment of students. It is envisaged that with the outcome of this study teachers and instructors will also be able to identify the various symptoms of test anxiety that manifest during testing and examinations situations and provide adequate counselling as remedy.

\section{METHODOLOGY}

In line with the positivist epistemology, this study adopted the cross-sectional descriptive survey design with quantitative approach. This design is deemed appropriate because it seeks to describe and interpret what exists in its present condition, attitudes, practices and beliefs (Polit \& Beck, 2014). Therefore, this research design is in agreement with the purpose of the study is to investigate the factors that elicit anxiety and advance coping strategies to reduce anxiety through self-report of the students. Using the proportionate stratified random sampling, a sample of 746 students was sampled from both public and private Junior High Schools in the three (3) circuits of the Effutu Municipality. Cassady and Johnson (2002) Cognitive Test Anxiety Scale (CTAS) was adopted and adapted in collecting data. The CTAS scale is a questionnaire which consist of twenty seven (27) items measured on a 4-point Likert scale such that $1=$ Not at all typical of me, $2=$ only somewhat typical of me, $3=$ Quite typical of me, and 4= Very typical of me. It required students to rate every option to describe their anxiety level. The questionnaire also contained 
items on factors that influence students' examination anxiety and coping strategies which were measured on a five-point Likert-scale such that strongly agree $(\mathrm{SA})=5$, Agree $(A)=4$, Neutral $(\mathrm{N})=3$, Disagree $(\mathrm{D})=2$, and Strongly Disagree $(\mathrm{SD})=1$.

In establishing the reliability of the instrument, a pre-test was carried out and the internal consistency assessment of the various items revealed 0.86 for examination anxiety construct, 0.87 for the factors influencing anxiety while 0.83 was realized for coping strategies using Cronbach alpha which is consistent with McMillan and Schumacher's (2010) recommendation of 0.70. Mean, and standard deviation as well as multiple regression were used for analysis after satisfying assumptions underlying the use of inferential statistics have been met. After meeting the ethical requirements of anonymity, confidentiality, and informed consent as criteria of conducting research, the researchers self-administered the instruments to the students.

\section{RESULTS AND DISCUSSION}

\section{Research Question 1 - What factors that influence examination anxiety among Junior High School students in the Effutu Municipality?}

The aim of this research question was to investigate the factors that accounts for examination anxiety among Junior High School students in the Effutu Municipality. Factors such as low selfconfidence, students past experience, psychological factors, study habits and skills, history of consistent poor performance, and the number of subjects pursued by the students were considered in the study. The results of the analysis are presented in Table 1.

\section{Table 1: Descriptive Statistics on Factors Influencing Examination Anxiety}

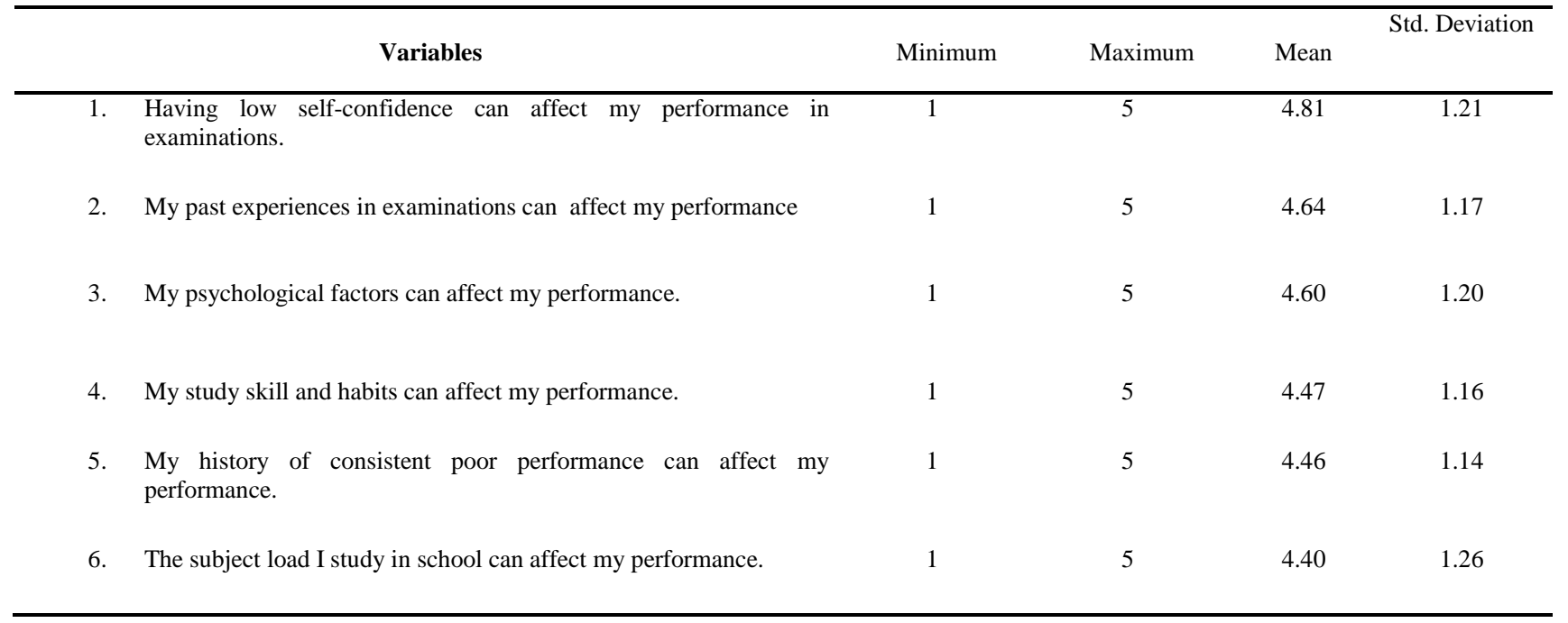

Source: Fieldwork, 2019

The information in Table 1 reveals the students perceived all the factors highlighted in this study influenced their anxiety level. Nonetheless, the students rated highest on low self-confidence 
International Journal of Education, Learning and Development

Vol.8, No.1, pp.51-65, January 2020

Published by ECRTD-UK

Print ISSN: 2054-6297(Print), Online ISSN: 2054-6300(Online)

$(\mathrm{M}=4.81, \mathrm{SD}=1.21)$, followed by past experiences and beliefs about examination $(\mathrm{M}=4.64$, $\mathrm{SD}=1.17)$, psychological factors $(\mathrm{M}=4.60, \mathrm{SD}=1.20)$, study skill and habits $(\mathrm{M}=4.47, \mathrm{SD}=1.16)$, history of consistent poor performance $(\mathrm{M}=4.46, \mathrm{SD}=1.14)$, while subject load $(\mathrm{M}=4.40$, $\mathrm{SD}=1.26$ ) was the least among the factors influencing anxiety. From these results, it could be observed low self-confidence greatly influenced anxiety while the subject load studied by the students was the least of the factors.

\section{Research Question 2 - What coping strategies are effective in managing examination anxiety among Junior High School students in the Effutu Municipality?}

This research question sought to elicit the views of the students on some coping strategies that could be deployed in managing examination anxiety. Review of literature has revealed that academicians have advanced some coping strategies in managing examination anxiety (Patil \& Aithala , 2017; Duraku, 2016 \& Aremu \& Sokan, 2003). Accordingly, factors such as good study habits, teacher support, motivation, reduced subject load, improving co-curricular activities, and ensuring rest and sleep were outlined and investigated. The results are presented in Table 2 . The data in Table 2 show that a variety of coping strategies could be adopted in managing examination anxiety in the schools. However, the findings revealed that the students rated highest good study habits $(\mathrm{M}=4.31, \mathrm{SD}=0.99)$, followed by good teacher support $(\mathrm{M}=4.29$, $\mathrm{SD}=1.04)$, student motivation $(\mathrm{M}=4.27, \mathrm{SD}=1.02)$, reduction of subject load $(\mathrm{M}=3.07, \mathrm{SD}=1.06)$, improving co-curricular activities $(\mathrm{M}=3.04, \mathrm{SD}=1.09)$, and having sleep and rest times $(\mathrm{M}=3.02$, $\mathrm{SD}=1.12$ ). Therefore, it was evident that having good study habits and skills was the dominant examination anxiety management strategy while ensuring sleep and rest was the least coping strategy as preferred by the students.

Table 2: Descriptive Statistics on Coping Strategies for Examination Anxiety

\begin{tabular}{|c|c|c|c|c|c|}
\hline \multicolumn{2}{|r|}{ Strategies } & \multirow{2}{*}{$\frac{\text { Minimum }}{1}$} & \multirow{2}{*}{$\frac{\text { Maximum }}{4}$} & \multirow{2}{*}{$\frac{\text { Mean }}{4.31}$} & \multirow{2}{*}{$\begin{array}{c}\text { Std. Deviation } \\
0.99\end{array}$} \\
\hline 1. & $\begin{array}{l}\text { Having good study habits is a sure way to assist students } \\
\text { reduce anxiety during examination }\end{array}$ & & & & \\
\hline 2. & $\begin{array}{l}\text { Having good teacher support for students is a sure way to assist } \\
\text { students reduce anxiety during examination }\end{array}$ & 1 & 4 & 4.29 & 1.04 \\
\hline 3. & Motivation of students can reduce anxiety during examination & 1 & 4 & 4.27 & 1.02 \\
\hline 4. & $\begin{array}{l}\text { Reduction of subject load of students can reduce anxiety } \\
\text { during examination }\end{array}$ & 1 & 4 & 3.07 & 1.06 \\
\hline 5. & $\begin{array}{l}\text { Improving co-curricular activities are a sure way to assist } \\
\text { students reduces anxiety during examination. }\end{array}$ & 1 & 4 & 3.04 & 1.09 \\
\hline 6. & $\begin{array}{l}\text { Ensuring sleep and rest time is a sure way to assist students } \\
\text { reduce anxiety during examination. }\end{array}$ & 1 & 4 & 3.02 & 1.12 \\
\hline
\end{tabular}

Source: Fieldwork, 2019 
International Journal of Education, Learning and Development

Vol.8, No.1, pp.51-65, January 2020

Published by ECRTD-UK

Print ISSN: 2054-6297(Print), Online ISSN: 2054-6300(Online)

Research Question 3 - To what extent does the factors (low self-confidence, psychological factors, subject load, history of consistent poor results, past experiences and beliefs about examination, study skills and habits) influence examination anxiety in Junior High Schools in the Effutu Municipality?

The third research question investigated the extent to which factors like having low selfconfidence, psychological factors, subjects load, history of consistent poor performance, past experiences and beliefs about examination and study skill influence examination anxiety among Junior High School students in the Effutu Municipality. Multiple regression was employed to provide answers to this research question, and the results are presented in Table 3.

Table 3: Model Summary of Multiple Regression Results for Factors Influencing Examination Anxiety

\begin{tabular}{lccccccccc}
\hline & & & & \multicolumn{3}{c}{ Std. Error } & \multicolumn{3}{c}{ Change Statistics } \\
Model & $\mathrm{R}$ & $\mathrm{R}^{2}$ & $\begin{array}{c}\text { Adjusted } \\
\text { of the }\end{array}$ & $\begin{array}{c}\mathrm{R}^{2} \\
\text { Estimate }\end{array}$ & $\begin{array}{c}\mathrm{F} \\
\text { Change }\end{array}$ & $\begin{array}{c}\text { Change } \\
\text { df1 }\end{array}$ & df2 & $\begin{array}{c}\text { Sig. F } \\
\text { Change }\end{array}$ \\
\hline 1 & $0.484^{\mathrm{a}}$ & 0.234 & 0.228 & 0.501 & 0.234 & 37.382 & 6 & 734 & 0.000 \\
\hline
\end{tabular}

a. Predictors: (Constant), Psychological factors., History of consistent poor performance, Study skill, Subjects load, Having low Self Confidence, Past experiences and beliefs about examination b. Dependent Variable: Test Anxiety

The multiple regression results in Table 3 revealed that factors such as psychological factors, history of consistent poor performance, study skills, subject load, having low self-confidence and past experiences and beliefs collectively accounted for $23.4 \%$ to examination anxiety which was considered to be statistically significant $[\mathrm{F}(6,734)=37.382, \mathrm{p}<0.05]$.

\section{Table 4: ANOVA Results for Factors Influencing Examination Anxiety}

\begin{tabular}{ccccccc}
\hline Model & $\begin{array}{c}\text { Sum of } \\
\text { Squares }\end{array}$ & df & $\begin{array}{c}\text { Mean } \\
\text { Square }\end{array}$ & F & Sig. \\
\hline $\mathbf{1}$ & Regression & 56.234 & 6 & 9.372 & 37.382 & $0.000^{\mathrm{b}}$ \\
& Residual & 184.026 & 734 & 0.251 & & \\
& Total & 240.260 & 740 & & & \\
\hline
\end{tabular}

a. Predictors: (Constant), Psychological factors., History of consistent poor performance, study skill, subjects load, having low self-confidence, past experiences and beliefs about examination b. Dependent Variable: Examination Anxiety

This result implies that other factors which were not included in this study were responsible for $76.6 \%$ influence on examination anxiety. Based on these results, it is evident that together, these factors were good predictors of examination anxiety among Junior High School Students in the Effutu Municipality. The study further examined the influence of each predictor to examination anxiety, and the results are presented in Table 5. 
International Journal of Education, Learning and Development

Vol.8, No.1, pp.51-65, January 2020

Published by ECRTD-UK

Print ISSN: 2054-6297(Print), Online ISSN: 2054-6300(Online)

Table 5: Standardized and Unstandardized Coefficients for Factors Influencing Examination Anxiety

\begin{tabular}{|c|c|c|c|c|c|c|c|c|}
\hline \multicolumn{2}{|c|}{ Model } & \multicolumn{2}{|c|}{$\begin{array}{c}\text { Unstandardized } \\
\text { Coefficients }\end{array}$} & \multirow{3}{*}{$\begin{array}{c}\begin{array}{c}\text { Standardized } \\
\text { Coefficients }\end{array} \\
\text { Beta }\end{array}$} & \multirow[b]{3}{*}{$\mathrm{t}$} & \multirow[b]{3}{*}{ Sig. } & \multicolumn{2}{|c|}{$\begin{array}{l}\text { Collinearity } \\
\text { Statistics }\end{array}$} \\
\hline & & \multirow{2}{*}{ B } & \multirow{2}{*}{$\begin{array}{l}\text { Std. } \\
\text { Error }\end{array}$} & & & & \multirow{2}{*}{ Tolerance } & \multirow{2}{*}{ VIF } \\
\hline & & & & & & & & \\
\hline \multirow[t]{7}{*}{1} & (Constant) & 1.679 & 0.070 & & 24.025 & 0.000 & & \\
\hline & Having low Self Confidence & 0.047 & 0.018 & 0.100 & 2.646 & 0.008 & 0.728 & 1.373 \\
\hline & $\begin{array}{l}\text { Past experiences and beliefs } \\
\text { about examination }\end{array}$ & 0.072 & 0.018 & 0.148 & 3.916 & 0.000 & 0.726 & 1.377 \\
\hline & $\begin{array}{l}\text { History of consistent poor } \\
\text { performance. }\end{array}$ & 0.109 & 0.019 & 0.217 & 5.848 & 0.000 & 0.756 & 1.322 \\
\hline & Subject Load. & 0.056 & 0.016 & 0.125 & 3.559 & 0.000 & 0.848 & 1.179 \\
\hline & Study skills and Habits. & 0.024 & 0.017 & 0.048 & 1.385 & 0.167 & 0.857 & 1.166 \\
\hline & Psychological factors & 0.072 & 0.016 & 0.152 & 4.461 & 0.000 & 0.901 & 1.109 \\
\hline
\end{tabular}

Source: Fieldwork, 2019

The results in Table 5 show that out of the six factors, having low self-confidence $(\beta=0.018$, $\mathrm{t}=2.646, \mathrm{p}<0.05)$, past experience and beliefs about examination $(\beta=0.148, \mathrm{t}=3.916, \mathrm{p}<0.05)$, history of consistent poor performance $(\beta=0.217, \mathrm{t}=5.848, \mathrm{p}<0.05)$, subject load $(\beta=0.125$, $\mathrm{t}=3.559, \mathrm{p}<0.05)$, and psychological factors $(\beta=0.152, \mathrm{t}=4.461, \mathrm{p}<0.05)$ individually contributed significantly to the examination anxiety while the contribution of study skills and habits was not significant $(\beta=0.048, \mathrm{t}=1.385, \mathrm{p}>0.05)$. Based on these findings, it was inferred that having low self-confidence, past experience and beliefs about examination, history of consistent poor performance, subject load, and psychological factors were the major factors that influenced examination anxiety among Junior High School students in the Effutu Municipality.

Research Question 4 - Relative to one another, which coping strategies (good study habits, having sleep and rest time, reduction of subject load, effective teacher support, improvement of co-curricular activities, motivation of students) better reduce examination anxiety among Junior High School students in the Effutu Municipality?

In this research question, the extent to which factors such as good study habits, sleep and rest time, reducing the subject load of students, Having good teachers' support for students, Improving co-curricular activities, and motivation of students trigger examination anxiety and the results of the multiple regression are shown in Table 6. 
International Journal of Education, Learning and Development

Vol.8, No.1, pp.51-65, January 2020

Published by $\boldsymbol{E C R T D}-\boldsymbol{U K}$

Print ISSN: 2054-6297(Print), Online ISSN: 2054-6300(Online)

Table 6: Model Summary of Multiple Regression Results for Coping Strategies and Examination Anxiety

\begin{tabular}{lccccccccc}
\hline & & & & \multicolumn{3}{c}{ Std. Error } & \multicolumn{4}{c}{ Change Statistics } \\
Model & $\mathrm{R}$ & $\mathrm{R}^{2}$ & $\begin{array}{c}\text { Adjusted } \\
\text { of the }\end{array}$ & $\begin{array}{c}\mathrm{R}^{2} \\
\text { Estimate }\end{array}$ & $\begin{array}{c}\mathrm{F} \\
\text { Change }\end{array}$ & $\begin{array}{c}\text { Change } \\
\text { df1 }\end{array}$ & $\begin{array}{c}\text { df2 } \\
\text { Change }\end{array}$ \\
\hline 1 & $0.346^{\mathrm{a}}$ & 0.119 & 0.112 & 0.537 & 0.119 & 16.590 & 6 & 734 & 0.000 \\
\hline
\end{tabular}

a. Predictors: (Constant), good study habits, having sleep and rest time, reduction of subject load of students, having good teacher support for students, improving co-curricular activities, motivation of students

b. Dependent Variable: Examination Anxiety

The multiple regression results in Table 6 reveal that good study habits, sleep and rest time, reducing the subject load of students, having good teachers' support for students, improving cocurricular activities, and motivation of students collectively accounted for $11.9 \%$ to examination anxiety which was considered to be statistically significant $[\mathrm{F}(6,734)=16.590, \mathrm{p}<0.05]$.

Table 6: ANOVA Results for Coping Strategies and Examination Anxiety

\begin{tabular}{|c|c|c|c|c|c|c|}
\hline & Model & $\begin{array}{l}\text { Sum of } \\
\text { Squares } \\
\end{array}$ & Df & $\begin{array}{c}\text { Mean } \\
\text { Square }\end{array}$ & $\mathrm{F}$ & Sig. \\
\hline \multirow[t]{3}{*}{1} & Regression & 28.692 & $\overline{6}$ & 4.782 & 16.590 & $0.000^{\mathrm{b}}$ \\
\hline & Residual & 211.568 & 734 & 0.288 & & \\
\hline & Total & 240.260 & 740 & & & \\
\hline
\end{tabular}

a. Dependent Variable: Examination Anxiety

b. Predictors: (Constant), Ensuring good study habits, ensuring sleep \& rest time, reducing the subject load of students, having good teachers' support for students, Improving co-curricular Act, and motivation of students

The result Table 6 imply that other factors that were not included in this study were responsible for $88.1 \%$ influence for examination anxiety. Based on these results, it was evident that together, these factors were good predictors of examination anxiety and existence of these factors could reduce examination anxiety and bolster academic performance among Junior High School students in the Effutu Municipality.

The study further examined the contribution of each predictor to examination anxiety, and the results are shown in Table 7. 
International Journal of Education, Learning and Development

Vol.8, No.1, pp.51-65, January 2020

Published by ECRTD-UK

Print ISSN: 2054-6297(Print), Online ISSN: 2054-6300(Online)

Table 7 Standardized and Unstandardized Coefficients for Coping Strategies and Examination Anxiety

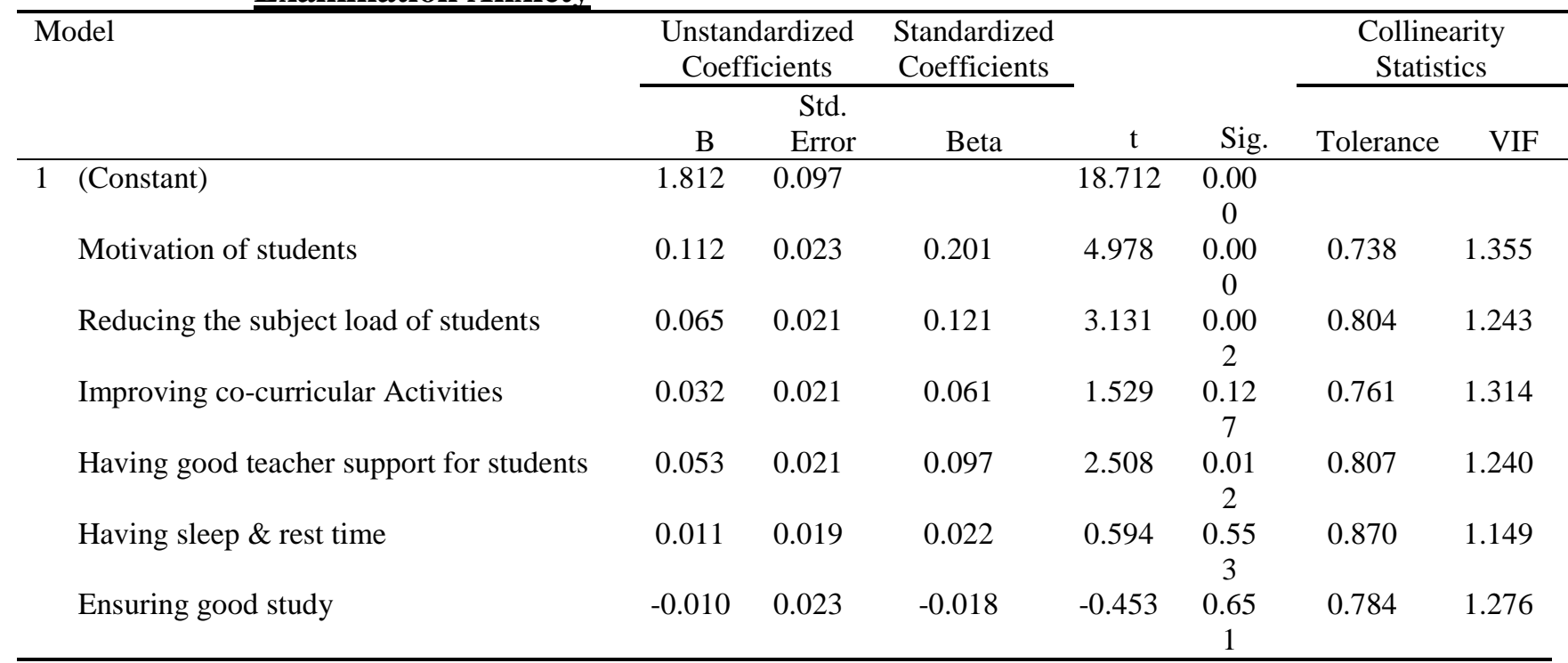

Source: Fieldwork, 2019

The results in Table 7 reveal that motivation of students $(\beta=0.201, \mathrm{t}=4.978, \mathrm{p}<0.05)$, reduction of subject load $(\beta=0.121, \mathrm{t}=3.131, \mathrm{p}<0.05)$ and having good teacher support for students $(\beta=0.097$, $\mathrm{t}=2.508, \mathrm{p}<0.05)$ made significant unique contribution to examination anxiety while improving co-curricular activities $(\beta=0.061, \mathrm{t}=1.529, \mathrm{p}>0.05)$, having sleep and rest time $(\beta=0.022, \mathrm{t}=0.594$, $\mathrm{p}<0.05)$ and ensuring good study habits $(\beta=-0.018, \mathrm{t}=-0.453, \mathrm{p}>0.05)$ did not contribute significantly to examination anxiety. However, the results prove that motivation of students contributed more to examination anxiety than reduction of subject load and good teacher support for students. Based on these results, it was concluded that motivation of students, reduction of subject load and good teacher support for students are crucial in reducing examination anxiety among students. Therefore, the existence of these factors is crucial in reducing examination anxiety and is likely to boost academic performance among Junior High School students in the Effutu Municipality.

\section{DISCUSSION OF RESULTS}

Research question one examined the factors that trigger examination anxiety among the students, and the results showed that generally, lack of self-esteem was the most dominant factor of the students' examination anxiety, followed by past experiences and beliefs, psychological factors, study skills and habits, history of consistent poor performance while subject load of the students recorded the least influence on examination anxiety. Nonetheless, it was noted that indeed all the factors outlined in this study had above average influence on students' examination anxiety. The findings of this study resonate with similar studies (Vaz, et al., 2018; Patil \& Aithala, 2017; Duraku, 2016; Chapell, et al., 2005) where factors such as low self-esteem, psychological, subject loads, past experiences, and consistent poor performance influenced the examination 
International Journal of Education, Learning and Development

Vol.8, No.1, pp.51-65, January 2020

Published by ECRTD-UK

Print ISSN: 2054-6297(Print), Online ISSN: 2054-6300(Online)

anxiety among students thereby confirming previous revelation that the factors that initiate examination anxiety among students are not only exhaustive to the aforementioned ones. Accordingly, attempts to address examination anxiety should involve a plethora of approaches since the adoption of single approach would not yield the expected results.

The findings on the second research question showed a myriad of coping strategies that could be used in managing examination anxiety among students. These included good study habits and skills, good teachers' support for students; motivation, reducing workloads, improving cocurricular activities, and ensuring enough sleep and rest time. The results of the study concur with previous studies (Maharajan, et al., 2017; Mashayekh \& Hashemi, 2011; MarszalWiśniewska, et al., 2011) where similar strategies were identified. Hence, a holistic approach needs to be sought and implemented to support the students cope with examination anxiety.

In relation to research question three, it was observed that factors such as having low selfconfidence, past experience and beliefs about examination, history of consistent poor performance, subject load, and psychological factors individually contributed significantly to the examination anxiety jointly contributed a significant $23.4 \%$ to examination anxiety among students while the contribution of study skills and habits was not significant. Other previous studies provided results similar to the findings of this study. For instance, Xiao (2013) discovered that reducing students' academic workloads improve students' mental and physical health could be adopted to deal with examination anxiety among students. Xiao further noted that improving extracurricular opportunities, and strictly following the schools' study and recess time schedule are necessary in dealing with examination anxiety. Others include ensuring enough sleep and rest time, and ensuring student-centered education system. Likewise, Maharajan, et al., (2017) noted that academic support in the form of teacher support mechanisms is central in dealing with examination anxiety among students. Paramount to this study was that the choice of coping strategy is influenced by various factors, hence, individuals involved in the management of examination need to identify these factors and the extent to which the factors impact their anxiety levels.

For the fourth research question, it was discovered that motivation of students, reduction of subject load and having good teachers' support for students all made significant unique contribution to examination anxiety and were deemed to be the needed coping strategies to manage examination anxiety as these strategies jointly contributed $11.9 \%$ to examination anxiety while improving co-curricular activities, ensuring sleep and rest time and ensuring good study habits did not contribute significantly to examination anxiety. However, the results proved that motivation of students contributed more to examination anxiety than reduction of subject load and good teacher support for students. Accordingly, it was inferred that motivation of students, reduction of subject load and good teacher support for students are crucial in reducing examination anxiety among students. This finding concurs with previous studies (Maharajan, et al., 2017; Mashayekh \& Hashemi, 2011; Marszal-Wiśniewska, et al., 2011) but however 
International Journal of Education, Learning and Development

Vol.8, No.1, pp.51-65, January 2020

Published by $\boldsymbol{E C R T D}-\boldsymbol{U K}$

Print ISSN: 2054-6297(Print), Online ISSN: 2054-6300(Online)

disagrees with Arul (2014) who established no significant relationship between study habits and test anxiety of students.

\section{CONCLUSIONS AND RECOMMENDATIONS}

In this study, it was established that lack of self-esteem, past experiences and beliefs, psychological factors, study skills and habits, history of consistent poor performance and subject load of the students generally influence anxiety during examination. These findings reinforce the argument that examination anxiety is an ever present educational phenomenon in the academic pursuit of students. Hence, education stakeholders should be preoccupied in finding pragmatic solutions aimed at reducing the anxiety levels of students if they desire to realize improved academic performance among the students. In this direction the coping strategies explored have unveiled development of good study habits, good teacher support, motivation of students, reducing subject loads, improving co-curricular activities, and ensuring adequate sleep and rest time among the students that need to be implemented for improved performance. To realize this, Guidance and Counseling Coordinators and Circuit Supervisors should be fortified with current theories in study habits so that they can offer necessary assistance to students on how to improve on their study habits.

Additionally, there should be regular education programmes such as symposia and school festivals should be conducted to heighten students' self-esteem, and remove negative past experiences and beliefs about examinations so that the students can confidently face the challenge of examinations with reasonable anxiety level. Another intriguing revelation that needs attention is the call from the students to education authorities to reduce the subject load. Education stakeholders should dialogue with the National Council for Curriculum and Assessment (NaCCA) to reduce the subjects studied at the Junior High School to realize good academic performance. This could be done by merging related themes and integrated into one syllabus so as to lessen the number of subjects studied.

\section{Suggestion for Further Studies}

It is proposed that the study is carried out in the entire country to determine the nature of the factors that trigger examination anxiety and also the coping strategies that could be employed to reduce examination anxiety. This will help develop a national strategy to deal with examination anxiety among students for improved academic performance in the entire country. Again, based on the finding that $76.6 \%$ in variance for the factors that trigger examination anxiety and $88.1 \%$ in variance for the coping strategies were unaccounted for by the variables involved in this study, it is suggested that further studies are conducted to examine other factors and coping strategies needed to deal with examination anxiety so as to realize improved academic performance.

\section{References}

Aremu, A. O., \& Sokan, B. O. (2003). A multi-causal evaluation of academic performance of Nigerians for National Development. Ibadan: MacMillan Nigeria. 
International Journal of Education, Learning and Development

Vol.8, No.1, pp.51-65, January 2020

Published by ECRTD-UK

Print ISSN: 2054-6297(Print), Online ISSN: 2054-6300(Online)

Arul-Lawrence, A. S. (2014). Relationship between study habits and test anxiety of higher secondary students. International Journal of Teacher Education Research, 3(6), 2319-4642.

Bensoussan, M. (2012). Alleviating test anxiety for students of advanced reading comprehension. RELC Journal, 43(2), 203-216.

Cassady, J.C., \& Johnson, R. E. (2002). Cognitive test anxiety and academic performance. Contemporary Educational Psychology, 27, 270-295.

Chapell, M. S., Blanding, Z.B., Takahashi, M., Silverstein, M. E., Newman, B., Gubi, A., \& Mccann, N. (2005). Test anxiety and academic performance in undergraduate and graduate students. Journal of Educational Psychology, 97 (2), 268-274.

Cherry, K. (2012). Causes of test anxiety http://www.psychology.about.com/od/mentalhealth/a/te st-anxiety-causes.htm - Retrieved 24th April, 2019.

Driscoll, R., Evans, G., Ramsey, G., \& Wheeler, S. (2009). High test anxiety among nursing students. Education Resources Information Center, 14(4), 350-356.

Duraku, Z. H., (2016). Factors influencing test anxiety among university students. The European Journal of Social and Behavioural Sciences, 18(1), 2325-2334.

Hashemi, M., \& Mashayekh, M. (2011). Recognizing, reducing and copying with test anxiety: Causes, solutions, and recommendations. Solutions and Recommendations. Procedia: Social and behavioral sciences, 30(2), 2149-2155.

Hoferichter, F., Raufelder, D., \& Eid, M. (2014). The mediating role of socio-motivational relationships in the interplay of perceived stress, neuroticism, and test anxiety among adolescent students. Psychology in the schools, 51(7), 736-752.

Karimi, A., \& Venkatesan, S. (2009). Mathematics anxiety, mathematics performance and academic hardiness in high school students. International Journal of Educational Sciences, 1 (1), 33-37.

Khan, Z., Haider, Z., Ahmed, N., \& Khan, S. (2011). Sports achievement motivation and sports competition anxiety: A relationship study. Journal of Education and Practice, 2, 1-5.

Maharajan, M., Rajiah, K., Tam, A., Chaw, S., Ang, M. \& Yong, M. (2017). Pharmacy students' anxiety towards research during their undergraduate degree; How to reduce it?. PLOS ONE, 12(4), 76-95.

Marszał-Wiśniewska, M., Goryńska, E., \& Strelau, J. (2011). Mood change in a stressful exam situation: The modifying role of temperament and motivational tendencies. Personality and Individual Differences, 52, 839-844.

Mavilidi, M., Hoogerheide, V., \& Paas, F. (2014). A quick and easy strategy to reduce test anxiety and enhance test performance. Applied Cognitive Psychology, 28, 72-726.

McMillan, J. H., \& Schumacher, S. (2010). Research in education: Evidence-based inquiry $\left(7^{\text {th }}\right.$ ed.). Boston, MA: Pearson.

Mondal, P., Ghosh, A., \& Das, S. S. (2013). Relationship between anxiety and achievement motivation of chess players. Physical Education, 3, 443-444.

Oladipo, S. E., Ogungbamila, A. B., \& Idemudia, E. S. (2015). Age and gender factors of test anxiety among undergraduate students in two southwestern Nigerian Universities. Gender and Behaviour, 13(2), 6737-6741. 
Patil, S. G. \& Aithala, M., R.,(2017). Exam anxiety: Its prevalence and causative factors among Indian medical students. National Journal of Physiology, Pharmacy and Pharmacology, 7(12), 1-6.

Polit, D. F., \& Beck, C. T. (2014). Essentials of nursing research: Appraising evidence for nursing practice $\left(8^{\text {th }}\right.$ ed.). Philadelphia, PA: Lippincott Williams \& Wilkins.

Syokwaa, K. A., Aloka, P. J. O., Oginga, O. J., \& Ndunge, N. F. (2014). The relationship between anxiety levels and academic achievement among students in selected secondary schools in Lang'ata District, Kenya. Journal of Educational and Social Research MCSER Publishing, Rome-Italy, 4(3), 22-38.

Vaz, C. J., Pothiyil, T. D., George, L. S., Alex, S., Pothiyil, D., \& Kamath, A. (2018). Factors influencing examination anxiety among undergraduate nursing students: An exploratory factor analysis. Journal of Clinical and Diagnostic Research, 12(7), 16-19.

Xiao, J. T. (2013). Academic stress, test anxiety, and performance in a Chinese high school sample: The moderating effects of coping strategies and perceived social suppor.t (Doctoral dissertation). Georgia State University, USA. 